\title{
Evaluation of Dual Therapy in Real Life Setting in Treatment-Naïve Turkish Patients with HCV Infection: A Multicenter, Retrospective Study
}

\author{
Yunus Gürbüz ${ }^{1}$, Necla Eren Tülek², Emin Ediz Tütüncü ${ }^{1}$, Süda Tekin Koruk ${ }^{3}$, Bilgehan Aygen ${ }^{4}$, \\ Neșe Demirtürk ${ }^{5}$, Sami Kınıklı², Ali Kaya ${ }^{6}$, Taner Yıldırmak ${ }^{7}$, Kaya Süer ${ }^{8}$, Fatime Korkmaz \\ Onur Ural ${ }^{10}$, Sıla Akhan ${ }^{11}$, Özgür Günal ${ }^{12}$, Nazan Tuna ${ }^{13}$, Şükran Köse ${ }^{14}$, İbak Gönen ${ }^{15}$, \\ Bahar Örmen ${ }^{16}$, Nesrin Türker ${ }^{16}$, Neşe Saltoğlu ${ }^{17}$, Ayşe Batırel ${ }^{18}$, Günay Tuncer ${ }^{2}$, Cemal Bulut ${ }^{2}$, \\ Fatma Sırmatel $^{19}$, Asım Ulçay ${ }^{20}$, Ergenekon Karagöz ${ }^{20}$, Derviş Tosun ${ }^{21}$, Alper Şener ${ }^{22}$, \\ Aynur Aynı $\breve{g l u}^{11}$, Elif Sargın Altunok ${ }^{11}$
}

\footnotetext{
${ }^{1}$ Department of Infectious Diseases and Clinical Microbiology, Dışkapı Yıldırım Beyazıt Training and Research Hospital, Ankara, Turkey ${ }^{2}$ Department of Infectious Diseases and Clinical Microbiology, Ankara Training and Research Hospital, Ankara, Turkey ${ }^{3}$ Department of Infectious Diseases and Clinical Microbiology, Harran University Faculty of Medicine, Şanlıurfa, Turkey ${ }^{4}$ Department of Infectious Diseases and Clinical Microbiology, Erciyes University Faculty of Medicine, Kayseri, Turkey ${ }^{5}$ Department of Infectious Diseases and Clinical Microbiology, Afyon Kocatepe University Faculty of Medicine, Afyonkarahisar, Turkey ${ }^{6}$ Department of Infectious Diseases and Clinical Microbiology, Mersin University Faculty of Medicine, Mersin, Turkey ${ }^{7}$ Department of Infectious Diseases and Clinical Microbiology, Okmeydanı Training and Research Hospital, İstanbul, Turkey ${ }^{8}$ Department of Infectious Diseases and Clinical Microbiology, Near East University Faculty of Medicine, Nicosia, North Cyprus ${ }^{9}$ Department of Infectious Diseases and Clinical Microbiology, Konya Training and Research Hospital, Konya, Turkey ${ }^{10}$ Department of Infectious Diseases and Clinical Microbiology, Selçuk University Faculty of Medicine, Konya, Turkey ${ }^{11}$ Department of Infectious Diseases and Clinical Microbiology, Kocaeli University Faculty of Medicine, Kocaeli, Turkey ${ }^{12}$ Department of Infectious Diseases and Clinical Microbiology, Gaziosmanpaşa University Faculty of Medicine, Tokat, Turkey ${ }^{13}$ Department of Infectious Diseases and Clinical Microbiology, Sakarya University Faculty of Medicine, Sakarya, Turkey ${ }^{14}$ Department of Infectious Diseases and Clinical Microbiology, Tepecik Training and Research Hospital, İzmir, Turkey ${ }^{15}$ Department of Infectious Diseases and Clinical Microbiology, Süleyman Demirel University Faculty of Medicine, Isparta, Turkey ${ }^{16}$ Department of Infectious Diseases and Clinical Microbiology, İzmir Katip Çelebi University Atatürk Training and Research Hospital, İzmir, Turkey ${ }^{17}$ Department of Infectious Diseases and Clinical Microbiology, İstanbul University Cerrahpaşa Faculty of Medicine, İstanbul, Turkey ${ }^{18}$ Department of Infectious Diseases and Clinical Microbiology, Kartal Dr. Lütfi Kırdar Training and Research Hospital, İstanbul, Turkey

${ }^{19}$ Department of Infectious Diseases and Clinical Microbiology, Abant İzzet Baysal University Faculty of Medicine, Bolu, Turkey

${ }^{20}$ Department of Infectious Diseases and Clinical Microbiology, GATA Haydarpaşa Training and Research Hospital, İstanbul, Turkey ${ }^{21}$ Department of Infectious Diseases and Clinical Microbiology, Ulus State Hospital, Ankara, Turkey

${ }^{22}$ Department of Infectious Diseases and Clinical Microbiology, Çanakkale Onsekiz Mart University Faculty of Medicine, Çanakkale, Turkey
}

Background: Before the introduction of direct-acting antivirals in the treatment of chronic hepatitis $\mathrm{C}$ patients, the combination of peginterferon alpha and ribavirin was the standard therapy. Observational studies that investigated sustained virological response (SVR) rates by these drugs yielded different outcomes.

Aims: The goal of the study was to demonstrate real life data concerning SVR rate achieved by peginterferon alpha plus ribavirin in patients who were treatment-naïve.
Study Design: A multicenter, retrospective observational study.

Methods: The study was conducted retrospectively on 1214 treatment naïve-patients, being treated with peginterferon alpha-2a or $2 \mathrm{~b}$ plus ribavirin in respect of the current guidelines between 2005 and 2013. The patients' data were collected from 22 centers via a standard form, which has been prepared for this study. The data included demographic and clinical characteristics (gender, age,

This study was presented at the APASL 2014, Conference of the Asian Pacific Association for the Study of the Liver, 12-15 March 2014, Brisbane, Australia.

Address for Correspondence: Dr. Yunus Gürbüz, Department of Infectious Diseases and Clinical Microbiology, Dışkapı Yıldırım Beyazıt Training and Research Hospital, Ankara, Turkey

Phone: +905325159984 e-mail: yunusgurbuz@outlook.com

Received: 16.06.2015 Accepted: 30.09.2015 • DOI: 10.5152/balkanmedj.2015.15859

Available at www.balkanmedicaljournal.org

Cite this article as:

Gürbüz Y, Tülek NE, Tütüncü EE, Tekin Koruk S, Aygen B, Demirtürk N, et al. Evaluation of dual therapy in real life setting in treatment-naïve Turkish patients with HCV infection: A multicenter, retrospective study. Balkan Med J 2016;33:18-26 
body weight, initial Hepatitis C virus RNA (HCV RNA) level, disease staging) as well as course of treatment (duration of treatment, outcomes, discontinuations and adverse events). Renal insufficiency, decompensated liver disease, history of transplantation, immunosuppressive therapy or autoimmune liver disease were exclusion criteria for the study. Treatment efficacy was assessed according to the patient's demographic characteristics, baseline viral load, genotype, and fibrosis scores.

Results: The mean age of the patients was $50.74( \pm 0.64)$ years. Most of them were infected with genotype 1 $(91.8 \%)$. SVR was achieved in $761(62.7 \%)$ patients. SVR rate was $59.1 \%$ in genotype $1,89.4 \%$ in genotype $2,93.8 \%$ in genotype 3 , and $33.3 \%$ in genotype 4 patients. Patients with lower viral load yielded higher SVR (65.8\% vs. $58.4 \%, \mathrm{p}=0.09)$. SVR rates according to histologic severity were found to be $69.3 \%, 66.3 \%, 59.9 \%$, $47.3 \%$, and $45.5 \%$ in patients with fibrosis stage $0,1,2$,
3 and 4, respectively. The predictors of SVR were male gender, genotype $2 / 3$, age less than 45 years, low fibrosis stage, low baseline viral load and presence of early virological response. SVR rates to each peginterferon were found to be similar in genotype 1/4 although SVR rates were found to be higher for peginterferon alpha- $2 b$ in patients with genotype $2 / 3$. The number of patients who failed to complete treatment due to adverse effects was $33(2.7 \%)$. The number of patients failed to complete treatment due to adverse effects was $33(2.7 \%)$.

Conclusion: Our findings showed that the rate of SVR to dual therapy was higher in treatment-naïve Turkish patients than that reported in randomized controlled trials. Also peginterferon alpha-2a and alpha- $2 \mathrm{~b}$ were found to be similar in terms of SVR in genotype 1 patients.

Keywords: Hepatitis C, peginterferon alpha-2a, peginterferon alpha- $2 \mathrm{~b}$, ribavirin, therapy
Hepatitis $\mathrm{C}$ virus (HCV) infection is a common disease all over the world, affecting nearly $3 \%$ of the world's population (1). The prevalence has been reported to be approximately $0.5-1 \%$ in the studies conducted in Turkey $(2,3)$. In a clinical series, the prevalence of cirrhosis within 20 years after detection of chronic hepatitis was found to be $24 \%$ (4). The annual risk of hepatocellular carcinoma (HCC) is between 2-6\% in patients who develop cirrhosis as a result of $\mathrm{HCV}$ infection (5). It has been demonstrated that sustained virological response (SVR) achieved with treatment in chronic hepatitis $\mathrm{C}$ patients and even in patients with advanced-stage liver fibrosis decreases the risk of hepatic insufficiency and liver-related mortality (6). In a meta-analysis, it was demonstrated that development of HCC could be prevented in patients receiving interferon, even if SVR has not been achieved (7).

The purpose of the treatment of chronic hepatitis $\mathrm{C}$ (CHC) is to achieve a virological cure. Before direct-acting antiviral drug-including regimes, SVR rates achieved in the first pivotal study performed using the combination of peginterferon alpha and ribavirin, which was the standard therapy for $\mathrm{CHC}$ patients, were found to be as follows: $54 \%$ in all genotypes (GTs), $42 \%$ in GT 1 , and over $80 \%$ in GT $2 / 3(8,9)$. In a similar study performed with peginterferon alpha-2a plus ribavirin, SVR rates were found to be $56 \%$ in overall GTs, $46 \%$ in GT $1,76 \%$ in GT 2 and 3 patients (10). GT 1 appears to be the most difficult to treat GT and more than $90 \%$ of Turkish patients are GT 1 (11).

Beside GT and HCV RNA levels, patient-related factors such as interleukin-28B polymorphism, age, body weight, ethnicity, steatosis, fibrosis, and insulin resistance affect SVR rates in patients receiving dual therapy $(9,10,12)$. If $\mathrm{HCV}$ RNA is undetectable at the fourth week of treatment, which is known as rapid virological response (RVR), SVR rate is around $90 \%$ (13). In recent years, real life data reported from various countries revealed different SVR rates from pivotal studies, and the reasons for these differences were discussed by authors. The present multi-center study has been conducted to obtain real life data regarding treatment outcomes in treatment-naïve CHC patients receiving dual therapy in Turkey.

\section{MATERIALS AND METHODS}

The present study was designed as a multicenter, retrospective study by the members of Viral Hepatitis Study Group which was formed within the body of Turkish Society of Clinical Microbiology and Infectious Diseases, between 2005 and 2013. The data of treatment-naïve CHC patients treated with peginterferon alpha plus ribavirin were collected. Twenty-two centers from different regions of Turkey participated in the study. Thirty researchers from the member centers of the group shared the data of 1214 patients, who met the predefined criteria, over the standard form that was delivered. The study protocol was approved by Dışkapı Yıldırım Beyazıt Training and Research Hospital, Ethics Committee for Clinical Researches. Considering patient privacy, patient information was recorded by coding. 


\section{Study design}

A form was developed for eligibility criteria and shared with the group members. Baseline data of treatment-naïve patients receiving peginterferon alpha-2 ( $\mathrm{a}$ or $\mathrm{b}$ ) plus ribavirin for $\mathrm{CHC}$, treatment protocol and doses, follow-up during treatment, data at the end of treatment and post-therapy follow-up were collected. Age, gender, liver histopathology, alanine aminotransaminase (ALT) and aspartate aminotransferase (AST) levels, HCV genotype, RVR, early virological response (EVR), end of treatment response (ETR), and SVR rates were recorded.

\section{Patient selection}

The study comprised treatment-naïve patients, who were over 18 years of age and had anti-HCV positivity and detectable HCV RNA for longer than six months. Twenty one patients co-infected with hepatitis B virus were also included. Patients with renal insufficiency, decompensated liver disease, history of transplantation, immunosuppressive therapy or autoimmune liver disease were not included in the study. Patients with a leucocyte count less than $3000 / \mathrm{mm}^{3}$ or neutrophil $<1500 / \mathrm{mm}^{3}$ and thrombocyte count $<90000 / \mathrm{mm}^{3}$ before therapy were also excluded. Patients in whom peginterferon plus ribavirin dose adjustment due to adverse events had not been performed in accordance with the guidelines, were not included in the study.

\section{Baseline parameters}

Patients' age, gender, pretreatment body weight, height, underlying diseases, baseline biochemical parameters (ALT, AST, total protein, albumin, alkaline phosphatase), complete blood count, prothrombin time, HBsAg, AntiHIV, liver histopathology, HCV RNA, genotype, and history of diabetes were recorded. HCV RNA levels were recorded quantitatively in $\mathrm{IU} / \mathrm{mL}$. Results from the centers that measured HCV RNA quantification in copy $/ \mathrm{mL}$ were transformed into $\mathrm{IU} / \mathrm{mL}$ using the transformer factor of the test. Liver biopsy was evaluated in accordance with the Metavir scoring system $(14,15)$ : F0, no fibrosis; F1, portal fibrosis without septa; F2, portal fibrosis with rare septa; F3, numerous septa without cirrhosis; and F4, cirrhosis. HCV RNA levels of the patients were analyzed at the beginning of treatment, at the fourth, $12^{\text {th }}$ and $24^{\text {th }}$ weeks over the course of treatment, at the end of treatment, and at the $24^{\text {th }}$ week after treatment. Complete blood count was analyzed at the second and fourth weeks and every four weeks thereafter over the course of treatment, whereas biochemical analyses were performed every four weeks. The doses of peginterferon and ribavirin, reasons for dose adjustments if any, and adverse effects were recorded.

\section{Treatment and defining the response}

The dose and duration of the dual combination therapy were in compliance with national and international guidelines: Weekly peginterferon alpha-2a (Pegasys; Hoffmann-la Roche, Switzerland) $180 \mu \mathrm{g}$ subcutaneously (SC) plus oral daily ribavirin (Copegus; Hoffman-la Roche, Switzerland) or peginterferon alpha-2b (Pegintron, Merck \& Co., Inc.; New Jersey, USA) $1.5 \mu \mathrm{g} / \mathrm{kg}$ SC per week plus oral daily ribavirin (Rebetol; Merck \& Co., Inc.; New Jersey, USA). Ribavirin dose was adjusted according to body weight in line with the recommendations of the manufacturers. Treatment durations were 24 weeks for HCV GT 2 and 3 or 48 weeks for HCV GT 1 and 4 patients.

Undetectable HCV RNA at the end of treatment was considered ETR, whereas undetectable HCV RNA at the $24^{\text {th }}$ week after treatment was considered SVR. Undetectable HCV RNA at the $12^{\text {th }}$ week of treatment was considered as EVR. Treatment was discontinued in those patients who had decline in viral load less than $2 \log$ at the $12^{\text {th }}$ week or who had detectable HCV RNA at the $24^{\text {th }}$ week of treatment since they were accepted as unresponsive. Undetectable HCV RNA at the fourth week of treatment was considered RVR. HCV RNA $<50 \mathrm{IU} / \mathrm{mL}$ was considered a loss of HCV RNA. Patients from the centers that had difficulty in accessing HCV RNA test and therefore could not perform HCV RNA analysis at the fourth or $12^{\text {th }}$ week were also included in the study, but effects of RVR and EVR on SVR could not be evaluated for those patients.

\section{Statistical analysis}

Baseline data of the patients were calculated as mean \pm SD or median. Categorical data were presented as numbers and ratio. Relation of baseline data with SVR was analyzed by using student's t-test and Mann-Whitney U-test or chi-square test The results were considered statistically significant if $\mathrm{p}<0.05$. Variances that reached statistical significance in univariate analysis were evaluated by multivariate logistic regression analysis. Stepwise and multivariate logistic regression models were used to explore the independent factors that could be used to predict SVR. Statistical analysis was carried out using SPSS program for Windows, version 15.0 J (SPSS; Chicago, IL, USA).

\section{RESULTS}

All of the participants were Caucasians and females accounted for the majority $(57.7 \%)$. The mean age of the patients was 50.74 years $( \pm 0.64)$. Of the patients, $8.7 \%$ were diabetic and $1.8 \%$ had hepatitis B co-infection. Since the study was retrospective and primarily aimed to determine SVR rates, 267 pa- 
tients with undetermined GT, 316 patients without biopsy, and 490 patients for whom body mass index could not be calculated were also included in the study. GT1 was found to be the predominant genotype $(91.8 \%)$ among those patients who underwent genotyping.

Histological findings of the liver were available for 898 patients; cirrhosis was present in only $2.4 \%$ of the patients with known fibrosis. Baseline demographic characteristics and laboratory findings of the patients are shown in Tables 1 and 2. In all GTs, the percentage of patients with SVR was $62.7 \%$. While SVR was $58.5 \%$ in GT $1 / 4$, it was found to be $90.7 \%$ in GT $2 / 3(p=0.001)$. SVR rate was considerably higher in GT $2 / 3$ patients compared to GT $1 / 4$ patients $(p=0.001)$. EVR was $73.7 \%$, whereas ETR rate was found to be $79.0 \%$.

TABLE 1. Baseline Characteristics of Study Subjects $(n=1214)$

\begin{tabular}{|c|c|}
\hline Characteristic & Number of patients and values \\
\hline Gender, Male/Female & $513 / 701(42.3 \% / 57.7 \%)$ \\
\hline Age (Mean) & $50.74( \pm 11.68)$ \\
\hline$<45$ & $314(25.9 \%)$ \\
\hline$\Rightarrow>45$ & $900(74.1 \%)$ \\
\hline \multicolumn{2}{|l|}{ Body Mass Index $(n=724)$} \\
\hline$<25$ & $248(34.3 \%)$ \\
\hline$\geq 25-<30$ & $338(46.7 \%)$ \\
\hline$\geq 30$ & $138(19.1 \%)$ \\
\hline \multicolumn{2}{|l|}{ Fibrosis stage $(n=898)$} \\
\hline 0 & $127(14.1 \%)$ \\
\hline 1 & $419(46.7 \%)$ \\
\hline 2 & $182(20.3 \%)$ \\
\hline 3 & $148(16.5 \%)$ \\
\hline 4 & $22(2.4 \%)$ \\
\hline \multicolumn{2}{|l|}{ Genotype $(n=947)$} \\
\hline 1 & $869(91.8 \%)$ \\
\hline 2 & $38(4 \%)$ \\
\hline 3 & $16(1.7 \%)$ \\
\hline 4 & $24(2.5 \%)$ \\
\hline Peginterferon alpha- $2 \mathrm{a} / 2 \mathrm{~b}$ & $618 / 596(50.9 \% / 49.1 \%)$ \\
\hline Diabetes mellitus & $106 / 1214(8.7 \%)$ \\
\hline Hepatitis B surface antigen positivity & $21 / 1198(1.8 \%)$ \\
\hline \multicolumn{2}{|l|}{ ALT, U/L (n=1214) } \\
\hline Mean & $68.73( \pm 50.96)$ \\
\hline Normal & $525(43.2 \%)$ \\
\hline Above upper limit of the normal & $689(56.8 \%)$ \\
\hline \multicolumn{2}{|l|}{ Hepatitis C virus RNA, } \\
\hline Median (min.-max.) & $625,500(372-5,200,000,000)$ \\
\hline$\geq 8 \times 105 \mathrm{IU} / \mathrm{mL}$ & $510 / 1214(42 \%)$ \\
\hline
\end{tabular}

SVR was evaluated according to the baseline characteristics of the patients. While SVR was $75.8 \%$ under the age of 45 years, it was found to be $58.1 \%$ over the age of 45 years $(p=0.001)$. ALT elevation was found in $54.7 \%$ of the patients. SVR rates were lower in the patients with higher ALT levels than those with normal ALT levels (59.2\% vs. 67.8\%). Likewise, SVR was also lower in the patients with higher AST levels (67.6\% vs. 56.1\%). HCV RNA level $\geq 800,000 \mathrm{IU} / \mathrm{mL}$

TABLE 2. Demographic characteristics of the patients receiving peginterferon alpha- $2 \mathrm{a}$ and $2 \mathrm{~b}$

\begin{tabular}{|c|c|c|c|c|}
\hline & $\begin{array}{l}\text { Peginterferon } \\
\text { alpha-2a n (\%) }\end{array}$ & $\begin{array}{l}\text { Peginterferon } \\
\text { alpha-2b n (\%) }\end{array}$ & Total & $\mathrm{p}$ \\
\hline \multicolumn{5}{|l|}{ Gender } \\
\hline Male & $276(44.6 \%)$ & $237(39.8 \%)$ & $513(42.3 \%)$ & \\
\hline Female & $343(55.4 \%)$ & $358(60.2 \%)$ & $701(57.7 \%)$ & $\mathrm{p}=0.094$ \\
\hline Total & $619(100 \%)$ & $595(100 \%)$ & $1214(100 \%)$ & NS \\
\hline \multicolumn{5}{|l|}{ Age } \\
\hline$<45$ & $170(27.5 \%)$ & $144(24.2 \%)$ & $314(25.9 \%)$ & \\
\hline $45-59$ & $310(50.1 \%)$ & $288(48.4 \%)$ & $598(49.3 \%)$ & $\mathrm{p}=0.111$ \\
\hline$\geq 60$ & $139(22.5 \%)$ & $163(27.4 \%)$ & $302(24.9 \%)$ & NS \\
\hline Total & $619(100 \%)$ & $595(100 \%)$ & $1214(100 \%)$ & \\
\hline \multicolumn{5}{|l|}{ BMI } \\
\hline Normal & $124(34.9 \%)$ & $124(33.6 \%)$ & $248(34.3 \%)$ & \\
\hline Overweight & $171(48.2 \%)$ & $167(45.3 \%)$ & $338(46.7 \%)$ & $\mathrm{p}=0.346$ \\
\hline Obese & $60(16.9 \%)$ & $78(21.1 \%)$ & $138(19.1 \%)$ & NS \\
\hline Total & $355(100 \%)$ & $369(100 \%)$ & $724(100 \%)$ & \\
\hline \multicolumn{5}{|l|}{ Genotype } \\
\hline 1,4 & $447(94.3 \%)$ & $446(94.3 \%)$ & $893(94.3 \%)$ & $\mathrm{p}=0.994$ \\
\hline 2,3 & $27(5.7 \%)$ & $27(5.7 \%)$ & $54(5.7 \%)$ & NS \\
\hline Total & $474(100 \%)$ & $473(100 \%)$ & $947(100 \%)$ & \\
\hline \multicolumn{5}{|l|}{ Fibrosis } \\
\hline 0 & $65(14.3 \%)$ & $62(14.0 \%)$ & $127(14.1 \%)$ & \\
\hline 1 & $209(45.9 \%)$ & $210(47.4 \%)$ & $419(46.7 \%)$ & \\
\hline 2 & $99(21.8 \%)$ & $83(18.7 \%)$ & $182(20.3 \%)$ & $\mathrm{p}=0.807$ \\
\hline 3 & $72(15.8 \%)$ & $76(17.2 \%)$ & $148(16.5 \%)$ & NS \\
\hline 4 & $10(2.2 \%)$ & $12(2.7 \%)$ & $22(2.4 \%)$ & \\
\hline Total & $455(100 \%)$ & $443(100 \%)$ & $898(100 \%)$ & \\
\hline \multicolumn{5}{|l|}{ HCV RNA } \\
\hline$<800000$ & $350(56.5 \%)$ & $354(59.5 \%)$ & $704(58.0 \%)$ & $\mathrm{p}=0.297$ \\
\hline$\geq 800000$ & $269(43.5 \%)$ & $241(40.5 \%)$ & $510(42.0 \%)$ & NS \\
\hline Total & $619(100 \%)$ & $595(100 \%)$ & $1214(100 \%)$ & \\
\hline \multicolumn{5}{|l|}{ Diabetes } \\
\hline No & $555(89.7 \%)$ & $553(92.9 \%)$ & $1108(91.3 \%)$ & $\mathrm{p}=0.043$ \\
\hline Yes & $64(10.3 \%)$ & $42(7.1 \%)$ & $106(8.7 \%)$ & $\mathrm{S}$ \\
\hline Total & $619(100 \%)$ & $595(100 \%)$ & $1214(100 \%)$ & \\
\hline
\end{tabular}


was considered as high viral load; accordingly, high viral load was detected in $42 \%$ of the patients. Median HCV RNA level was $625,500 \mathrm{IU} / \mathrm{mL}$. SVR was higher in those patients with lower viral load (65.8\% vs. 58.4\%, $\mathrm{p}=0.09)$.

Patients who had low fibrosis accounted for the majority of the study group; the frequencies of fibrosis stages were as follows: stage $0,14 \%$; stage $1,46.7 \%$; stage $2,20.3 \%$; stage 3 , $16.5 \%$; and stage 4 (cirrhosis), $2.4 \%$. SVR rates according to fibrosis stages (0 through 4 ) were found to be $69.3 \%, 66.3 \%$, $59.9 \%, 47.3 \%$, and $45.5 \%$, respectively.

Two hundred and fifty-four patients $(20.92 \%)$ could not complete the treatment because of unresponsiveness to therapy or adverse effects. Treatment was discontinued at the $12^{\text {th }}$ or $24^{\text {th }}$ week due to complete or partial non-response in $186(15.32 \%)$ and due to breakthrough in $35(2.88 \%)$ patients, whereas 33 (2.71\%) patients failed to complete the study due to adverse events. While SVR rate was $47.2 \%$ in diabetic patients, it was found to be $64.2 \%$ in non-diabetic patients $(p=0.001)$. Any effect of HBsAg positivity on SVR was not determined.

Rapid virological response was evaluated in only 645 patients and was determined in $43.3 \%$ of these patients. SVR was higher in those with RVR $(79.6 \%$ vs. $43.2 \%, p=0.001)$. SVR was achieved in $78.1 \%$ of the patients with EVR and in $8.7 \%$ of those without EVR ( $p=0.001$ ). Relationship between SVR and demographic and clinical features of the study group are given in Table 3 .

In the study group, $50.9 \%$ of the patients received peginterferon alpha-2a and $49.1 \%$ received peginterferon alpha- $2 b$. We found no differences between two interferons in terms of SVR $(63.0 \%$ vs. $62.4 \%$, p=0.814). We also evaluated pergenotype differences in SVR rates according to the type of peginterferon used (Table 4). Peginterferon alpha-2b appears to be associated with higher SVR rates in GT $2 / 3$ patients when compared with alpha-2a (96.3\% versus $85.2 \%, \mathrm{p}>0.001)$, although we could not find any statistically significant difference between two drugs in patients with GT $1 / 4(p=0.891)$.

Multivariate logistic regression analysis revealed positive correlation between SVR and male gender, EVR and the age under 45 years (Table 5).

The most common adverse effects were weight loss, myalgia, fever and headache. While $27 \%$ of the patients required dose reduction for ribavirin due to anemia, the dose of peginterferon was reduced in $7 \%$ patients due to neutropenia. Treatment discontinuation was required due to adverse events in $2.7 \%$ of the patients. Common adverse effects are presented in Table 6.

\section{DISCUSSION}

Although the seroprevalence of $\mathrm{CHC}$ is about $1 \%$ in Turkey, HCV is ranked second in the etiology of HCC after
TABLE 3. Relationship between demographic and clinical characteristics and SVR $(\mathrm{n}=1214)$ (Chi-Square tests)

\begin{tabular}{|c|c|c|}
\hline Demographic and clinical characteristics & SVR $(\%)$ & $\mathrm{p}$ \\
\hline \multicolumn{3}{|l|}{ Age } \\
\hline$<45$ & 75.8 & $\mathrm{p}=0.001$ \\
\hline$\Rightarrow>45$ & 58.1 & \\
\hline \multicolumn{3}{|l|}{ Gender } \\
\hline Male & 63.7 & $\mathrm{p}=0.515$ \\
\hline Female & 61.9 & \\
\hline \multicolumn{3}{|l|}{ Body Mass Index } \\
\hline$<25$ & 68.1 & \\
\hline$\geq 25-<30$ & 58.9 & $\mathrm{p}=0.010$ \\
\hline$\geq 30$ & 53.9 & \\
\hline Diabetes Mellitus & 47.2 & $\mathrm{p}=0.001$ \\
\hline Non diabetics & 64.2 & \\
\hline \multicolumn{3}{|l|}{ Genotype } \\
\hline 1,4 & 58.5 & $\mathrm{p}=0.001$ \\
\hline 2,3 & 90.7 & \\
\hline \multicolumn{3}{|l|}{ Fibrosis (Metavir) } \\
\hline 0 & 69.3 & \\
\hline 1 & 66.3 & \\
\hline 2 & 59.9 & $\mathrm{p}=0.001$ \\
\hline 3 & 47.3 & \\
\hline 4 & 45.5 & \\
\hline \multicolumn{3}{|l|}{ HCV RNA } \\
\hline$\geq 800,000$ & 58.4 & $\mathrm{p}=0.09$ \\
\hline$<800,000$ & 65.8 & \\
\hline \multicolumn{3}{|l|}{ HBV Co-infection } \\
\hline Yes & 66.7 & $\mathrm{p}=0.444$ \\
\hline No & 62.5 & \\
\hline \multicolumn{3}{|l|}{ Peginterferon } \\
\hline Alpha-2a $(\mathrm{n}=619)$ & 63.0 & $\mathrm{p}=0.814$ \\
\hline Alpha-2b $(\mathrm{n}=595)$ & 62.4 & \\
\hline \multicolumn{3}{|l|}{$\mathrm{ALT}, \mathrm{U} / \mathrm{L}$} \\
\hline Normal & 67.8 & $\mathrm{p}=0.02$ \\
\hline Above upper limit of the normal & 59.2 & \\
\hline \multicolumn{3}{|l|}{ AST, U/L } \\
\hline Normal & 67.6 & \\
\hline Above upper limit of the normal & 56.1 & $\mathrm{p}=0.001$ \\
\hline \multicolumn{3}{|l|}{ Rapid virological response } \\
\hline Yes & 79.6 & $\mathrm{p}=0.001$ \\
\hline No & 43.2 & \\
\hline \multicolumn{3}{|l|}{ EVR } \\
\hline Yes & 78.1 & $\mathrm{p}=0.001$ \\
\hline No & 8.7 & \\
\hline
\end{tabular}

SVR: sustained virological response; HBV: hepatitis B virus; ALT: alanine aminotransaminase; AST: aspartate aminotransferase; EVR: early virological response; HCV: hepatitis C virus 
TABLE 4. Comparison of peginterferon alpha-2a vs. peginterferon alpha-2b according to SVR

\begin{tabular}{lcc}
\hline & SVR $(\%)$ & $\mathrm{p}$ \\
\hline All genotypes & & \\
$\quad$ Peginterferon alpha-2a $(\mathrm{n}=619)$ & 63.0 & $\mathrm{p}=0.814$ \\
Peginterferon alpha-2b $(\mathrm{n}=595)$ & 62.4 & \\
Genotype 2, 3 & & \\
Peginterferon alpha-2a $(\mathrm{n}=27)$ & 85.2 & $\mathrm{p}<0.001$ \\
$\quad$ Peginterferon alpha-2b $(\mathrm{n}=27)$ & 96.3 & \\
Genotype 1, 4 & & $\mathrm{p}=0.891$ \\
Peginterferon alpha-2a & 58.9 & \\
Peginterferon alpha-2b & 58.4 &
\end{tabular}

SVR: sustained virological response

TABLE 5. Multivariate Logistic Regression analysis to identify factors associated with SVR after peginterferon plus ribavirin therapy in treatment-naïve chronic hepatitis $\mathrm{C}$ patients with $\mathrm{HCV}$ genotype 1

\begin{tabular}{lccc}
\hline Factor & OR & $95 \% \mathrm{CI}$ & $\mathrm{p}$ \\
\hline Male gender & 1.956 & $1.107-3.453$ & 0.021 \\
Age $<45$ years & 3.630 & $1.689-3.020$ & 0.002 \\
EVR & 24.111 & $3.915-19.083$ & 0.001 \\
RVR & 1.490 & $0.802-2.770$ & 0.207 \\
ALT & 0.770 & $0.359-1.651$ & 0.502 \\
AST & 0.750 & $1.597-0.455$ & 0.455 \\
HCV-RNA & 0.758 & $0.406-1.306$ & 0.287 \\
Genotype & 3.203 & $0.712-14.416$ & 0.129 \\
Fibrosis 1 & 1.157 & $0.432-3106$ & 0.773 \\
Fibrosis 2 & 0.852 & $0.279-2.605$ & 0.779 \\
Fibrosis 3 & 0.565 & $0.173-1.846$ & 0.345 \\
Fibrosis 4 & 2.048 & $0.283-14.796$ & 0.477 \\
\hline
\end{tabular}

OR: odds ratio; CI: confidence interval; HCV: hepatitis C virus; EVR: early virological response; RVR: rapid virological response; ALT: alanine aminotransaminase; AST: aspartate aminotransferase

hepatitis B virus (16-18). Therefore, the treatment of such patients is important to prevent the development of cirrhosis or, if it has already developed, progression to HCC or hepatic insufficiency, and accordingly to reduce liver-related mortality. Long-term follow-up shows that response is permanent in $99 \%$ of the patients with SVR $(19,20)$. In the pivotal studies performed using standard therapy, which consists of peginterferon plus ribavirin, SVR rate was $54-56 \%$ for overall genotypes in treatment-naïve patients and it was reported that SVR rate was $42-52 \%$ for GT 1 patients $(9,10,13)$. Real life data indicate that SVR rates are usually higher than pivotal studies. Park et al. (21) conducted a study in Korea and evaluated the data of 758 patients; they found SVR rate to be $59.6 \%$ in all GTs, $53.6 \%$ in GT 1 , and $71.4 \%$ in GTs $2 / 3$. Similar results were obtained in two studies conducted in Ar-
TABLE 6. Frequency of adverse events for peginterferon alpha plus ribavirin

\begin{tabular}{lc}
\hline Adverse Events & $\%$ \\
\hline Fever & 50 \\
Headache & 50 \\
Myalgia & 56 \\
Weight loss & 59 \\
Injection site inflammation & 13 \\
Arthralgia & 11 \\
Nausea & 18 \\
Alopecia & 10 \\
Depression & 13 \\
Insomnia & 12 \\
Hyperthyroidism & 4 \\
Hypothyroidism & 0.2 \\
Anemia $(<10 \mathrm{gr} / \mathrm{dL})$ & 27 \\
Neutropenia $\left(<750 \mathrm{cell} / \mathrm{mm}^{3}\right)$ & 7 \\
Thrombocytopenia $\left(<50,000 / \mathrm{mm}^{3}\right)$ & 2 \\
\hline
\end{tabular}

gentina and Italy $(22,23)$. In France, the outcomes obtained by Bourliere et al. (24) were similar to the pivotal studies. In Turkey, there has been no large-scale study published regarding the results of dual therapy. Yenice et al. (25) conducted a study with 74 GT 1 treatment-naïve patients and determined the rate of SVR to be $48.6 \%$ in those treated with peginterferon alpha-2a and $35.1 \%$ in those treated with peginterferon alpha-2b. Dogan et al. (26) found 57.0\% and $52.3 \%$ SVR rate in those treated with peginterferon alpha-2a and peginterferon alpha- $2 \mathrm{~b}$, respectively, in a study consisting of $151 \mathrm{CHC}$ patients with GT 1. In this multicenter study, we have found SVR rate of $59.1 \%$ in GT1 patients, which is higher than both the pivotal studies and the studies published previously in Turkey.

As shown in many studies, SVR rate in GT 2/3 patients is higher than for GT 1 patients $(9,10,13)$. As is expected, we also have found higher SVR rates in GTs 2/3 as compared to GTs $1 / 4(90.7 \%$ vs. $58.5 \%, p=0.001)$. Another factor that enhances SVR was low viral load before treatment $(9,13,24)$. In the present study, SVR rate was also higher $(65.8 \%)$ in patients with low viral load than those of higher viral load $(58.4 \%)(p=0.09)$. Other patient-related factors that positively affect SVR were found to be young age, low body weight and low fibrosis stage. It is known that SVR rate is low in patients with advanced-stage fibrosis, particularly with cirrhosis (27). The rate of cirrhotic patients was $2.4 \%$ in this study. This rate was found to be $29 \%$ by Manns et al. (9) and $12 \%$ by Fried et al. (10). We conclude that the lower number of cirrhotic patients in this study group is one of the important reasons for higher SVR rates found in our study. 
Diabetes and insulin resistance are more common in patients with $\mathrm{CHC}$ and the presence of insulin resistance leads to rapid progression of fibrosis and reduction in SVR rates (28-31). While SVR rate was $47.2 \%$ in our diabetic patients, it was $64.2 \%$ in non-diabetic patients. SVR rate was found to be lower in the patients in whom ALT was above the upper limit of normal. The effect of HBV co-infection on SVR could not be demonstrated.

The probability of SVR correlates with the rapidity of $\mathrm{HCV}$ RNA suppression (32). Logistic regression analysis revealed that EVR was one of the three independent factors that influenced SVR.

Either peginterferon alpha-2a or alpha-2b is recommended together with ribavirin in the standard dual therapy for $\mathrm{CHC}$ $(33,34)$. In the pivotal studies, no substantial difference regarding SVR was detected between these two drugs $(9,10)$. Many studies, being conducted later on, evaluated whether these two drugs were superior to each other. Asconi, Rumi and Awad found that peginterferon alpha-2a was superior to peginterferon alpha-2b (35-37). However, in other studies carried out by McHutchison et al. (38) and Jin et al. (39), no difference was found between peginterferon alpha- $2 a$ and $2 b$ in terms of SVR. In two studies conducted in GT 1 patients in Turkey, no difference was found between two peginterferons. Our study is one of the largest series seeking for the SVR differences between two drugs and we have found peginterferon alpha- $2 \mathrm{a}$ and $2 b$ to be similar in terms of the SVR $(25,40)$. Different SVR rates have also been shown between two peginterferons according to genotypes (41). In this study, higher SVR rates were obtained in GTs $2 / 3$ with peginterferon alpha-2b, but no difference has been shown in GTs $1 / 4$ patients.

It is known that gender usually has no effect on $\operatorname{SVR}(22,23)$. In our study, multivariate analysis showed higher SVR rates in males. There are also studies suggesting that response is better in male gender $(21,25,35)$.

Treatment discontinuation due to laboratory abnormality and adverse events was encountered in $2.7 \%$ of the patients. This rate is lower than 10 and $11 \%$, which were obtained in the pivotal studies performed for peginterferon alpha-2a and $2 \mathrm{~b}$. We think that this is related to the low rate of patients with advanced fibrosis $(9,10,42)$.

Dual therapy with peginterferon alpha plus ribavirin has been being replaced by triple combinations of direct-acting antiviral drugs with peginterferons in many countries. Although SVR rates obtained by new therapies are better than standard therapy, it will be difficult for new antiviral therapies to replace the standard therapy in many countries due to the cost of new treatment regimes. Moreover, the fact that telaprevir and boceprevir, included in the triple therapy, are used in only GT 1 , leads to more adverse events than dual therapy, dis- play interactions with many drugs, and cause resistant strains. Dual therapy may be preferred in young and treatment-naïve patients, with low fibrosis and low viral load, particularly in resource limited settings.

In conclusion, this study comprises the "real life" results of peginterferon alpha plus ribavirin therapy in a large group of treatment-naïve Turkish patients. Our data suggest that the rate of SVR to peginterferon alpha plus ribavirin therapy was higher than those reported in randomized controlled trials. SVR rates to peginterferon alpha- $2 \mathrm{a}$ and alpha- $2 \mathrm{~b}$ treatments were found to be similar in GTs $1 / 4$ although SVR rates were found to be higher for peginterferon alpha-2b in patients with GTs 2/3.

Ethics Committee Approval: Ethics committee approval was received for this study from the ethics committee of Dışkapı Yıldırım Beyazit Training and Research Hospital.

Informed Consent: Written informed consent was obtained from patients who participated in this study.

Peer-review: Externally peer-reviewed.

Author contributions: Concept - Y.G., N.E.T., E.E.T.; Design Y.G., N.E.T.; Supervision - Y.G., N.E.T.; Resource - Y.G., N.E.T., E.E.T., S.T.K., B.A., N.D., S.K., A.K., T.Y., K.S., F.K., O.U., S.A., Ö.G., N.T., Ş.K., İ.G., B.Ö., N.T., N.S., A.B., G.T., C.B., F.S., A.U., E.K., D.T., A.Ş., A.A., E.S.A.; Materials -Y.G., N.E.T., E.E.T., S.T.K., B.A., N.D., S.K., A.K., T.Y., K.S., F.K., O.U., S.A., Ö.G., N.T., Ş.K., İ.G., B.Ö., N.T., N.S., A.B., G.T., C.B., F.S., A.U., E.K., D.T., A.Ş., A.A., E.S.A.; Data Collection \&/or Processing - Y.G., N.E.T., E.E.T., S.T.K., B.A., N.D., S.K., A.K., T.Y., K.S., F.K., O.U., S.A., Ö.G., N.T., Ş.K., İ.G., B.Ö., N.T., N.S., A.B., G.T., C.B., F.S., A.U., E.K., D.T., A.Ş., A.A., E.S.A.; Analysis \&/or Interpretation -Y.G., N.E.T., E.E.T.; Literature Search -Y.G, N.T.; Writing - Y.G., N.E.T., E.E.T.; Critical Reviews - Y.G., N.E.T., E.E.T., S.T.K., B.A., N.D., S.K., A.K., T.Y., K.S., F.K., O.U., S.A., Ö.G., N.T., Ş.K., İ.G., B.Ö., N.T., N.S., A.B., G.T., C.B., F.S., A.U., E.K., D.T., A.Ş., A.A., E.S.A.

Conflict of Interest: No conflict of interest was declared by the authors.

Financial Disclosure: The authors declared that this study has received no financial support.

\section{REFERENCES}

1. Alter MJ. The epidemiology of acute and chronic hepatitis C. Clin Liver Dis 1997;1:559-68, vi-vii. [CrossRef]

2. Balik I, Tosun S, Tabak F, Saltoglu N, Ormeci N, Sencan I, et al. Investigation of viral hepatitis epidemiology by a touring/travelling team [Turkish Viral Hepatitis Society Bus Project]. APASL Brisbane: Hepatology International; 2014. p. 1-405. 
3. Dayan S, Tekin A, Tekin R, Dal T, Hosoglu S, Yazgan UC, et al. HBsAg, anti-HCV, anti-HIV 1/2 and syphilis seroprevalence in healthy volunteer blood donors in southeastern Anatolia. J Infect Dev Ctries 2013;7:665-9. [CrossRef]

4. Freeman AJ, Dore GJ, Law MG, Thorpe M, Von Overbeck J, Lloyd AR, et al. Estimating progression to cirrhosis in chronic hepatitis C virus infection. Hepatology 2001;34:809-16. [CrossRef]

5. Sangiovanni A, Del Ninno E, Fasani P, De Fazio C, Ronchi G, Romeo R, et al. Increased survival of cirrhotic patients with a hepatocellular carcinoma detected during surveillance. Gastroenterology 2004;126:1005-14. [CrossRef]

6. Veldt BJ, Heathcote EJ, Wedemeyer H, Reichen J, Hofmann WP, Zeuzem S, et al. Sustained virologic response and clinical outcomes in patients with chronic hepatitis $\mathrm{C}$ and advanced fibrosis. Ann Intern Med 2007;147:677-84. [CrossRef]

7. Miyake Y, Iwasaki Y, Yamamoto K. Meta-analysis: reduced incidence of hepatocellular carcinoma in patients not responding to interferon therapy of chronic hepatitis C. Int $J$ Cancer 2010;127:989-96.

8. Strader DB, Wright T, Thomas DL, Seeff LB; American Association for the Study of Liver D. Diagnosis, management, and treatment of hepatitis C. Hepatology 2004;39:1147-71. [CrossRef]

9. Manns MP, McHutchison JG, Gordon SC, Rustgi VK, Shiffman M, Reindollar R, et al. Peginterferon alfa- $2 b$ plus ribavirin compared with interferon alfa-2b plus ribavirin for initial treatment of chronic hepatitis $\mathrm{C}$ : a randomised trial. Lancet 2001;358:958-65. [CrossRef]

10. Fried MW, Shiffman ML, Reddy KR, Smith C, Marinos G, Goncales FL Jr., et al. Peginterferon alfa-2a plus ribavirin for chronic hepatitis C virus infection. N Engl J Med 2002;347:975-82. [CrossRef]

11. Buruk CK, Bayramoglu G, Reis A, Kaklikkaya N, Tosun I, Aydin F. Determination of hepatitis $\mathrm{C}$ virus genotypes among hepatitis C patients in Eastern Black Sea Region, Turkey. Mikrobiyol Bul 2013;47:650-7. [CrossRef]

12. Ge D, Fellay J, Thompson AJ, Simon JS, Shianna KV, Urban TJ, et al. Genetic variation in IL28B predicts hepatitis C treatmentinduced viral clearance. Nature 2009;461:399-401. [CrossRef]

13. Hadziyannis SJ, Sette H Jr, Morgan TR, Balan V, Diago M, Marcellin P, et al; PEGASYS International Study Group. Peginterferon-alpha2a and ribavirin combination therapy in chronic hepatitis C: a randomized study of treatment duration and ribavirin dose. Ann Int Med 2004;140:346-55. [CrossRef]

14. Bedossa P, Poynard T. An algorithm for the grading of activity in chronic hepatitis C. The METAVIR Cooperative Study Group. Hepatology 1996;24:289-93. [CrossRef]

15. Intraobserver and interobserver variations in liver biopsy interpretation in patients with chronic hepatitis C. The French METAVIR Cooperative Study Group. Hepatology 1994;20:1520. [CrossRef]

16. Ozer B, Serin E, Yilmaz U, Gumurdulu Y, Saygili OB, Kayaselcuk F, et al. Clinicopathologic features and risk factors for he- patocellular carcinoma: results from a single center in southern Turkey. Turk J Gastroenterol 2003;14:85-90.

17. Alacacioglu A, Somali I, Simsek I, Astarcioglu I, Ozkan M, Camci C, et al. Epidemiology and survival of hepatocellular carcinoma in Turkey: outcome of multicenter study. Jpn J Clin Oncol 2008;38:683-8. [CrossRef]

18. Uzunalimoglu O, Yurdaydin C, Cetinkaya H, Bozkaya H, Sahin T, Colakoglu S, et al. Risk factors for hepatocellular carcinoma in Turkey. Dig Dis Sci 2001;46:1022-8. [CrossRef]

19. Swain MG, Lai MY, Shiffman ML, Cooksley WG, Zeuzem S, Dieterich DT, et al. A sustained virologic response is durable in patients with chronic hepatitis $\mathrm{C}$ treated with peginterferon alfa-2a and ribavirin. Gastroenterology 2010;139:1593-601. [CrossRef]

20. Thompson AJ, Muir AJ, Sulkowski MS, Ge D, Fellay J, Shianna $\mathrm{KV}$, et al. Interleukin-28B polymorphism improves viral kinetics and is the strongest pretreatment predictor of sustained virologic response in genotype 1 hepatitis C virus. Gastroenterology 2010;139:120-9.e18. [CrossRef]

21. Park SH, Park CK, Lee JW, Kim YS, Jeong SH, Kim YS, et al. Efficacy and tolerability of peginterferon alpha plus ribavirin in the routine daily treatment of chronic hepatitis $\mathrm{C}$ patients in Korea: a multi-center, retrospective observational study. Gut Liver 2012;6:98-106. [CrossRef]

22. Ridruejo E, Adrover R, Cocozzella D, Fernandez N, Reggiardo MV. Efficacy, tolerability and safety in the treatment of chronic hepatitis $\mathrm{C}$ with combination of PEG-Interferon - Ribavirin in daily practice. Ann Hepatol 2010;9:46-51.

23. Borroni G, Andreoletti M, Casiraghi MA, Ceriani R, Guerzoni $\mathrm{P}$, Omazzi B, et al. Effectiveness of pegylated interferon/ribavirin combination in 'real world' patients with chronic hepatitis C virus infection. Aliment Pharmacol Ther 2008;27:790-7. [CrossRef]

24. Bourliere M, Ouzan D, Rosenheim M, Doffoel M, Marcellin P, Pawlotsky JM, et al. Pegylated interferon-alpha2a plus ribavirin for chronic hepatitis $\mathrm{C}$ in a real-life setting: the Hepatys French cohort (2003-2007). Antivir Ther 2012;17:101-10. [CrossRef]

25. Yenice N, Mehtap O, Gumrah M, Arican N. The efficacy of pegylated interferon alpha $2 \mathrm{a}$ or $2 \mathrm{~b}$ plus ribavirin in chronic hepatitis C patients. Turk J Gastroenterol 2006;17:94-8.

26. Dogan UB, Akin MS, Yalaki S. Sustained virological response based on the week 4 response in hepatitis $\mathrm{C}$ virus genotype 1 patients treated with peginterferons alpha- $2 \mathrm{a}$ and alpha-2b, plus ribavirin. Eur J Gastroenterol Hepatol 2013;25:1317-20. [CrossRef]

27. Kau A, Vermehren J, Sarrazin C. Treatment predictors of a sustained virologic response in hepatitis B and C. J Hepatol 2008;49:634-51. [CrossRef]

28. D’Souza R, Sabin CA, Foster GR. Insulin resistance plays a significant role in liver fibrosis in chronic hepatitis $\mathrm{C}$ and in the response to antiviral therapy. Am J Gastroenterol 2005;100:1509-15. [CrossRef]

29. Cua IH, Hui JM, Kench JG, George J. Genotype-specific interactions of insulin resistance, steatosis, and fibrosis in chronic hepatitis C. Hepatology 2008;48:723-31. [CrossRef] 
30. Romero-Gomez M, Del Mar Viloria M, Andrade RJ, Salmeron J, Diago M, Fernandez-Rodriguez CM, et al. Insulin resistance impairs sustained response rate to peginterferon plus ribavirin in chronic hepatitis C patients. Gastroenterology 2005;128:636-41. [CrossRef]

31. Dai CY, Huang JF, Hsieh MY, Hou NJ, Lin ZY, Chen SC, et al. Insulin resistance predicts response to peginterferon-alpha/ ribavirin combination therapy in chronic hepatitis C patients. $J$ Hepatol 2009;50:712-8. [CrossRef]

32. Ferenci P, Fried MW, Shiffman ML, Smith CI, Marinos G, Goncales FL Jr, et al. Predicting sustained virological responses in chronic hepatitis $\mathrm{C}$ patients treated with peginterferon alfa-2a (40 KD)/ribavirin. J Hepatol 2005;43:425-33. [CrossRef]

33. Ghany MG, Strader DB, Thomas DL, Seeff LB; American Association for the Study of Liver D. Diagnosis, management, and treatment of hepatitis C: an update. Hepatology 2009;49:1335-74. [CrossRef]

34. European Association for the Study of the L. EASL Clinical Practice Guidelines: management of hepatitis C virus infection. J Hepatol 2011;55:245-64. [CrossRef]

35. Ascione A, De Luca M, Tartaglione MT, Lampasi F, Di Costanzo GG, Lanza AG, et al. Peginterferon alfa-2a plus ribavirin is more effective than peginterferon alfa-2b plus ribavirin for treating chronic hepatitis $\mathrm{C}$ virus infection. Gastroenterology 2010;138:116-22. [CrossRef]

36. Rumi MG, Aghemo A, Prati GM, D'Ambrosio R, Donato MF, Soffredini R, et al. Randomized study of peginterferon-alpha2a plus ribavirin vs peginterferon-alpha2b plus ribavirin in chronic hepatitis C. Gastroenterology 2010;138:108-15. [CrossRef]

37. Awad T, Thorlund K, Hauser G, Stimac D, Mabrouk M, Gluud C. Peginterferon alpha-2a is associated with higher sustained virological response than peginterferon alfa-2b in chronic hepatitis C: systematic review of randomized trials. Hepatology 2010;51:1176-84. [CrossRef]

38. McHutchison JG, Lawitz EJ, Shiffman ML, Muir AJ, Galler $\mathrm{GW}$, McCone $\mathrm{J}$, et al. Peginterferon alfa-2b or alfa-2a with ribavirin for treatment of hepatitis C infection. $N$ Engl J Med 2009;361:580-93. [CrossRef]

39. Jin YJ, Lee JW, Lee JI, Park SH, Park CK, Kim YS, et al. Multicenter comparison of PEG-IFN alpha2a or alpha2b plus ribavirin for treatment-naive $\mathrm{HCV}$ patient in Korean population. BMC Gastroenterol 2013;13:74. [CrossRef]

40. Dogan UB, Atabay A, Akin MS, Yalaki S. The comparison of the efficacy of pegylated interferon alpha-2a and alpha- $2 b$ in chronic hepatitis C patients with genotype 1. Eur J Gastroenterol Hepatol 2013;25:1082-5. [CrossRef]

41. Hauser G, Awad T, Brok J, Thorlund K, Stimac D, Mabrouk $\mathrm{M}$, et al. Peginterferon plus ribavirin versus interferon plus ribavirin for chronic hepatitis C. Cochrane Database Syst Rev 2014;2:CD005441. [CrossRef]

42. Fried MW. Side effects of therapy of hepatitis C and their management. Hepatology 2002;36:S237-44. [CrossRef] 